\title{
Newly isolated lactic acid bacteria from silage targeting biofilms of foodborne pathogens during milk fermentation
}

\author{
Elizaveta Gavrilova', Elizaveta Anisimova', Alsu Gabdelkhadieva², Elena Nikitina1,2, Adel Vafina², Dina Yarullina', \\ Mikhail Bogachev ${ }^{1,3}$ and Airat Kayumov ${ }^{1 *}$ (D)
}

\begin{abstract}
Background: Raw milk, meat and plant materials are subjected to high risks of contamination by various pathogenic bacteria and thus their growth prevention is a great challenge in the food industry. Food fermentation by lactic acid bacteria (LAB) besides changing its organoleptic characteristics also helps to eliminate unfavorable microflora and represses growth of pathogens. To the date only few LABs has been reported to exhibit activity against bacteria embedded in the biofilms characterized by extreme resistance to antimicrobials, high exchange rate with resistance genes and represent high risk factor for foodborne disease development.

Results: Six novel LAB strains isolated from the clover silage exhibited pronounced antibacterial activity against biofilm embedded pathogens. We show explicitly that these strains demonstrate high acidification rate, completely repress the growth of $E$. coli, S. aureus and to a lesser extent $P$. aeruginosa as well as exhibit appropriate probiotic and milk-fermenting properties. Moreover, in contrast to the approved probiotic strain Lactobacillus plantarum $8 \mathrm{PA} 3$, the new isolates were able to efficiently eradicate preformed biofilms of these pathogens and prevent bacterial spreading originating from the biofilm. We suggest these strains as potential additives to the pre-cultures of conventional LAB strains as efficient tools targeting foodborne pathogens in order to prevent food contamination from either seeded raw material or biofilm-fouled equipment.

Conclusions: The AG10 strain identified as L. plantarum demonstrate attractive probiotic and milk fermentation properties as well as high resistance to simulated gastric conditions thus appearing perspective as a starter culture for the prevention of bacterial contamination originating from fouled equipment during milk fermentation.
\end{abstract}

Keywords: Lactic acid bacteria, Lactobacillus, Antagonism, Biofilms, Milk fermentation

\section{Background}

Fermented milk products constitute significant part of the human nutrition with their quality and safety largely depending on both the milk itself and the starter cultures used for its fermentation. During fermentation process, Lactic acid bacteria (LAB) produce various metabolites thereby changing organoleptic characteristics of the substrates. In particular, fermentation of substrates improves digestibility and nutritional quality of the final product, enriches it with vitamins, essential amino acids and fatty acids [1].

\footnotetext{
* Correspondence: kairatr@yandex.ru

${ }^{1}$ Kazan Federal University, 18 Kremlevskaya Str, 420008 Kazan, Russia

Full list of author information is available at the end of the article
}

Another important role of $\mathrm{LAB}$ is the prevention of pathogenic microorganisms growth thus reducing the risks of foodborne disease development (for a detailed review, we refer to [2-5]). The raw (unpasteurized) milk, meat and other raw materials often contain a variety of pathogenic bacteria which should be eliminated during the fermentation [6, 7]. Thus, various LAB metabolites like organic acids, hydrogen peroxide and bacteriocins act as bio-preservative agents thereby improving food safety and extending the storage period of the final product [2]. Therefore the growth, acidification rate and antimicrobial activity are the most important properties of newly isolated strains as potential candidates for biotechnological and food industry applications [8-10]. 
The antagonistic properties of $\mathrm{LAB}$ seem to be attractive also for targeting pathogens in biofilm embedded forms [11-14]. Biofilm is a complex three-dimensional microbial consortium where bacteria are embedded in an extracellular matrix of organic polymers produced by bacteria themselves [15-17]. The matrix drastically reduces the susceptibility of bacteria to different outer stress factors [18] providing up to 1000-fold higher tolerance to antimicrobials of the biofilm-embedded cells compared to their planktonic counterparts [19-22]. Recent data indicates that LAB efficiently prevent the biofilm formation as well as exterminate biofilm-embedded pathogens like Staphylococcus epidermidis, Staphylococcus aureus, Citrobacter freundii, Enterobacter cloaceae, Klebsiella oxytoca, Proteus mirabilis and Candida albicans [23-29]..

The spectrum of metabolites produced by LAB is strongly strain-specific, and thus the appropriate choice of the starter bacterial strain with specific characteristics determines the final product properties and quality [3033]. Given the great variety of properties manifested by different strains, screening of novel LABs exhibiting attractive biological and technological properties until now remains one of key research directions in food microbiology.

Lactic acid bacteria are widely distributed in natural fermented foods as indigenous microflora [34] making such products a common source of lactic acid bacteria with potentially interesting functional and technological properties as well as perspective probiotics. Although traditionally LAB stains were isolated from the raw milk of various animals and naturally fermented dairy products [35-38], in recent years there is an increased interest to LAB strains with potential probiotic properties from unconventional sources like fecal samples, soil and fruits, especially as a part of dietary for subjects with lactose intolerance (for a detailed review, we refer to [39]). Despite increasing interest, to the date only few studies described the isolation of indigenous LAB stains from the silage [40-42] indicate that quite little information is available regarding their microbial ecology and thus also about their potential usefulness for dairy production.

Here we report the isolation and characterization of LABs from clover silage produced in the Republic of Tatarstan, Russia, exhibiting high anti-biofilm activity and probiotic properties.

\section{Results}

\section{Antibacterial activity of LAB}

From the 5-month fermented clover silage, the natural habitat of LAB, 120 catalase-negative isolates forming the highest halo zones on $\mathrm{CaCO}_{3}$-containing plates were selected and subjected to further screening for antibacterial activity. Out of the 120 colonies initially subjected to screening, six isolates exhibiting the most pronounced antagonistic properties against various pathogenic bacteria in agar diffusion test were selected (Table 1).

For all selected LAB strains with the exception of AG9 zones of inhibition of pathogens growth were significantly higher or comparable with those of the industrial probiotic strain L. plantarum 8PA3. Since the activity against bacteria embedded in biofilms has been previously reported only for few LAB, the biofilm-eradicating activity of these novel LAB strains was tested explicitly. For that, the suspensions of LAB $\left(10^{7} \mathrm{CFU} / \mathrm{mL}\right)$ in MRS broth were added to the wells with 48 -h old biofilms pre-formed by pathogenic bacteria washed with sterile saline to simulate the contaminated/biofouled surface, and the incubation was continued for the next $24 \mathrm{~h}$. Then the CFUs numbers of pathogens and LAB have been differentially counted by using differential media in the culture liquid (Fig. 1, upper lane) and in the residual biofilm (Fig. 1, lower lane). No repression of B. cereus spreading from the biofilm and consequent growth could be observed in the presence of any of the LAB. On the other hand, no viable $S$. aureus cells were detected in both culture liquid and biofilm after $24 \mathrm{~h}$ of cocultivation with any of the LAB strains with the exception of AG15. Remarkably, AG16 and AG10 strains led to almost complete eradication of both $P$. aeruginosa and $E$. coli in the biofilm. Of note, the probiotic strain $L$. plantarum 8PA3 exhibited the lowest rate of the pathogens growth repression in both culture liquid and biofilms.

CFUs number of LAB themselves in all mixed cultures insignificantly decreased in comparison with monocultures and remained within the range $10^{8}-10^{10} \mathrm{CFU} / \mathrm{mL}$, while in the presence of $P$. aeruginosa CFUs number of AG9, AG10, AG15 and AG16 decreased by 3-4 orders of magnitude (Additional file 1: Fig. S1), apparently, as a consequence of strong antagonistic interactions of $P$. aeruginosa with many other bacteria including LAB [43].

When the pathogens and LAB strains were inoculated together in the MRS broth at equal cell densities to simulate the contamination and incubated for $48 \mathrm{~h}$, pronounced repression of $S$. aureus and E. coli could be observed (Fig. 2). Moreover, the AG16 strain significantly repressed also the growth and the biofilm formation by $B$. cereus. In marked contrast, no significant repression of $P$. aeruginosa by any of the LAB could be observed despite the CFUs number of LAB in all mixed cultures remained within the range of $10^{6}-10^{10} \mathrm{CFU} / \mathrm{mL}$ (Additional file 1: Fig. S2).

\section{The acidification rate}

Among many tools of LAB providing their antagonistic properties against other bacteria, the synthesis of various organic acids leading to the acidification of the broth 
Table 1 Antimicrobial activity of $L A B$ strains isolated from silage (agar drop diffusion test)

\begin{tabular}{|c|c|c|c|c|c|c|}
\hline \multirow[t]{2}{*}{ LAB species } & \multirow[t]{2}{*}{ Strain } & \multicolumn{5}{|c|}{ Growth inhibition, mm } \\
\hline & & $\begin{array}{l}\text { Escherichia coli } \\
\text { MG1655 (K-12) }\end{array}$ & $\begin{array}{l}\text { Klebsiella pneumonia } \\
\text { (Clinical isolate) }\end{array}$ & $\begin{array}{l}\text { Pseudomonas } \\
\text { aeruginosa ATCC } 27853\end{array}$ & $\begin{array}{l}\text { Bacillus cereus } \\
\text { (Clinical isolate) }\end{array}$ & $\begin{array}{l}\text { Staphylococcus aureus subsp. } \\
\text { aureus ATCC } 29213\end{array}$ \\
\hline $\begin{array}{l}\text { Lactobacillus } \\
\text { plantarum }\end{array}$ & AG1 & $8.5 \pm 2.1$ & $10.0 \pm 2.8^{*}$ & $13.0 \pm 2.8^{*}$ & $5.5 \pm 2.1$ & $9.0 \pm 1.4$ \\
\hline $\begin{array}{l}\text { Lactobacillus } \\
\text { fermentum }\end{array}$ & AG8 & $8.5 \pm 2.1$ & $9.5 \pm 0.7$ & $13.0 \pm 2.8^{*}$ & $6.5 \pm 0.7^{*}$ & $9.5 \pm 0.7^{*}$ \\
\hline $\begin{array}{l}\text { Lactobacillus } \\
\text { plantarum }\end{array}$ & AG9 & $8.5 \pm 2.1$ & $8.5 \pm 2.1$ & $8.0 \pm 2.8$ & $6.0 \pm 0.3$ & $7.5 \pm 2.1$ \\
\hline $\begin{array}{l}\text { Lactobacillus } \\
\text { plantarum }\end{array}$ & AG10 & $8.0 \pm 1.4$ & $11.0 \pm 1.4^{*}$ & $11.0 \pm 1.4^{*}$ & $6.0 \pm 1.4$ & $9.5 \pm 0.7^{*}$ \\
\hline $\begin{array}{l}\text { Lactobacillus } \\
\text { plantarum }\end{array}$ & AG15 & $10.0 \pm 0.2^{*}$ & $11.5 \pm 0.7^{*}$ & $12.5 \pm 3.5^{*}$ & $6.5 \pm 0.7^{*}$ & $9.0 \pm 0.2$ \\
\hline $\begin{array}{l}\text { Lactobacillus } \\
\text { fermentum }\end{array}$ & AG16 & $9.0 \pm 1.4$ & $13.0 \pm 0.2^{*}$ & $12.5 \pm 3.5^{*}$ & $7.0 \pm 0.2^{*}$ & $9.5 \pm 2.1^{*}$ \\
\hline $\begin{array}{l}\text { Lactobacillus } \\
\text { plantarum }\end{array}$ & 8PA3 & $7.5 \pm 1.6$ & $7.9 \pm 0.6$ & $9.1 \pm 0.4$ & $5.0 \pm 0.5$ & $8.0 \pm 1.3$ \\
\hline
\end{tabular}

* denotes statistically significant difference with probiotic strain L. plantarum 8PA3 $(p<0.05)$

and repression of growth of other bacteria appears the keynote factor. The acidification rate was examined after $24 \mathrm{~h}$ growth in MRS broth in monoculture as well as after addition to 48 -h old biofilms pre-formed by pathogenic bacteria (Table 2). In monocultures, all six LAB strains reduced the $\mathrm{pH}$ values by $3.2-3.6$ units of standard $\mathrm{pH}$ scale and the total titratable acidity (TTA) of the culture liquid increased up to $1-2 \mathrm{~mL}$ in comparison with $0.5 \mathrm{~mL}$ in the initial broth. When LAB suspension in MRS have been added to the pre-established bacterial biofilms, a considerable reduction of the $\mathrm{pH}$ decrease could be observed in plates containing E. coli or P. aeruginosa, while no significant changes in comparison with $\mathrm{LAB}$ monocultures have been detected in the wells containing either $S$. aureus or B. cereus biofilms. Similarly, in the presence of either S. aureus or B. cereus biofilms the TTA increased up to $1.3-1.5 \mathrm{~mL}$ that was significantly higher in comparison with the probiotic strain L. plantarum 8PA3. On the contrary, in the plates containing $E$. coli or $P$. aeruginosa biofilms the TTA changed by $0.3-0.6 \mathrm{~mL}$ only.

In the experiments with simultaneous inoculation of LAB with B. cereus, E. coli or $S$. aureus their acidification activity was comparable with the corresponding monocultures level (Table 3) leading to the repression of growth and biofilm formation by E. coli and S. aureus, although less efficient (Fig. 2). By contrast, no acidification could be observed in the $P$. aeruginosa-LAB mixed

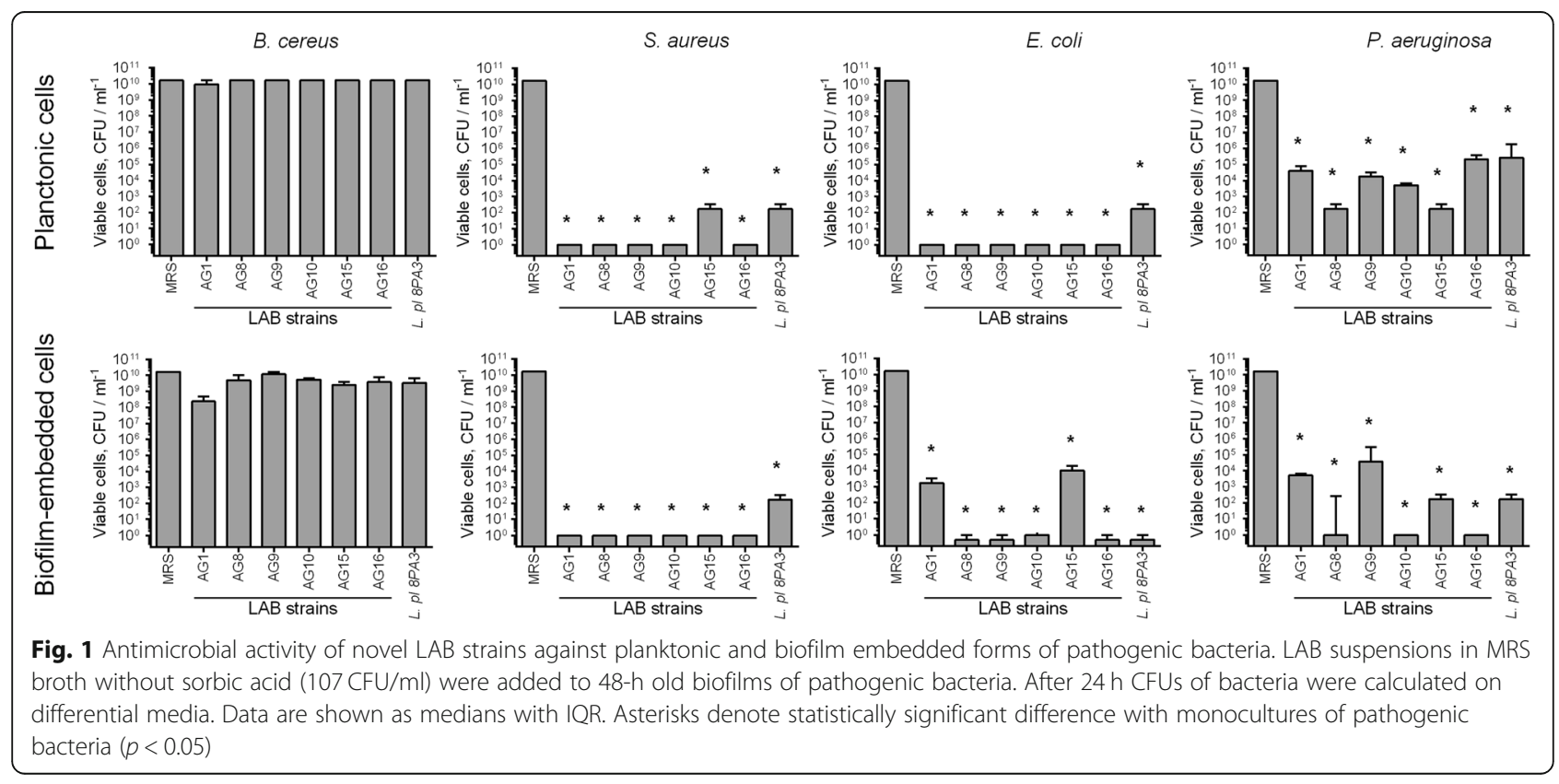




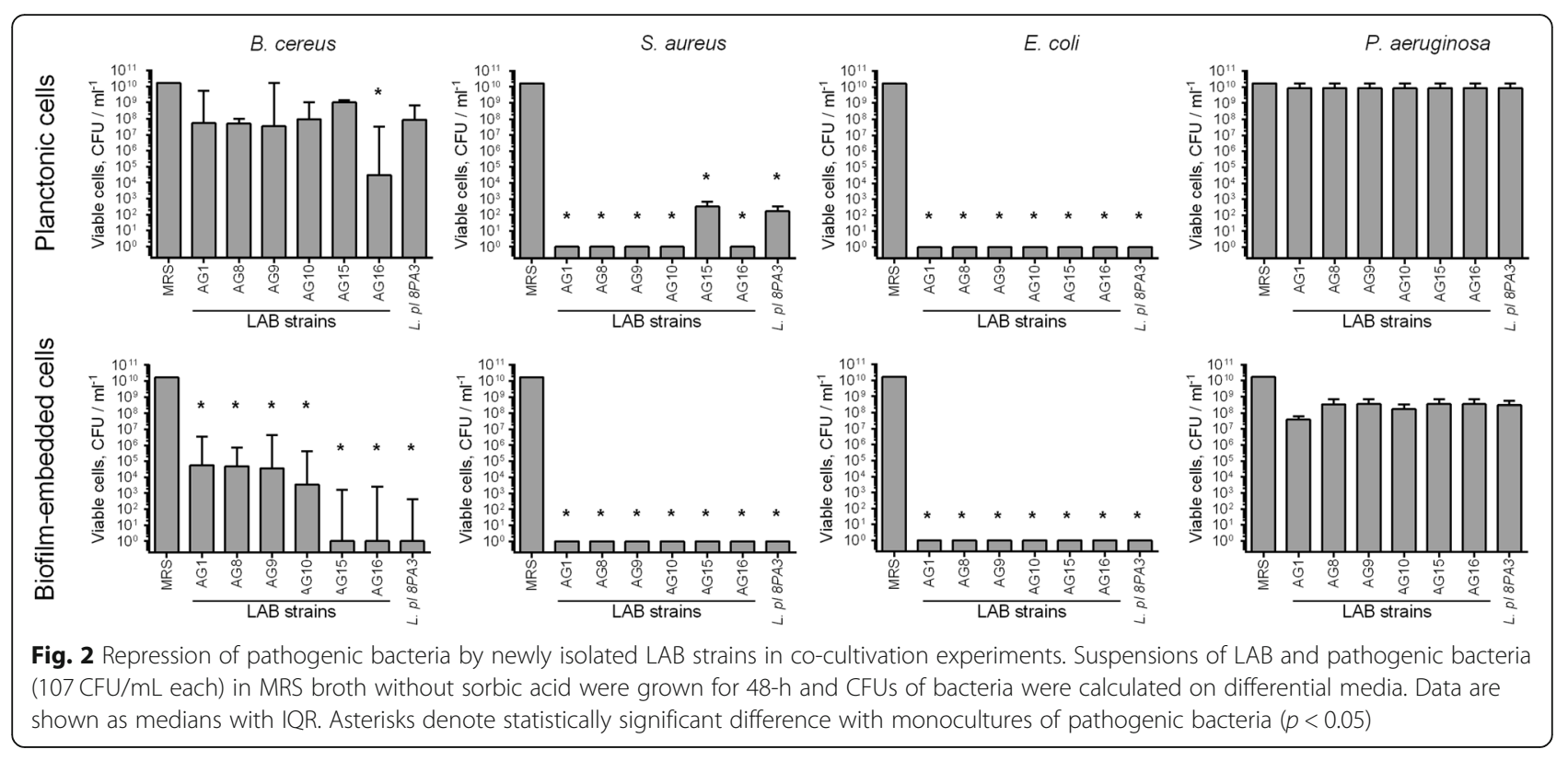

Table 2 The broth ${ }^{\ddagger}$ acidification rate by novel LAB strains isolated from silage growing in wells with 48-h old biofilms of pathogenic bacteria

\begin{tabular}{|c|c|c|c|c|c|c|c|c|c|}
\hline & Glucose & Strains & $\begin{array}{l}\text { L. plantarum } \\
\text { AG } 1\end{array}$ & $\begin{array}{l}\text { P. acidilactici } \\
\text { AG } 8\end{array}$ & $\begin{array}{l}\text { L. plantarum } \\
\text { AG } 9\end{array}$ & $\begin{array}{l}\text { L. plantarum } \\
\text { AG } 10\end{array}$ & $\begin{array}{l}\text { L. plantarum } \\
\text { AG } 15\end{array}$ & $\begin{array}{l}\text { L. fermentum } \\
\text { AG } 16\end{array}$ & $\begin{array}{l}\text { L. plantarum } \\
\text { 8PA3 }\end{array}$ \\
\hline \multirow[t]{10}{*}{$\Delta \mathrm{pH}$} & \multirow[t]{5}{*}{$2 \%$} & $\angle A B$ monoculture & $3.4 \pm 0.35^{*}$ & $3.2 \pm 0.24^{*}$ & $3.4 \pm 0.31^{*}$ & $3.6 \pm 0.56^{*}$ & $3.3 \pm 0.23^{*}$ & $3.2 \pm 0.11^{*}$ & $2.3 \pm 0.15$ \\
\hline & & P. aeruginosa & $2.5 \pm 0.55$ & $2.6 \pm 0.22^{*}$ & $2.5 \pm 0.54$ & $2.5 \pm 0.5$ & $2.4 \pm 0.39$ & $3.1 \pm 0.91^{*}$ & $2.4 \pm 0.51$ \\
\hline & & S. aureus & $3.1 \pm 0.21^{*}$ & $3.1 \pm 0.14^{*}$ & $3.1 \pm 0.21^{*}$ & $3.1 \pm 0.23^{*}$ & $3.1 \pm 0.23^{*}$ & $3.2 \pm 0.25^{*}$ & $2.8 \pm 0.25$ \\
\hline & & E. coli & $2.0 \pm 0.11$ & $2.0 \pm 1.08$ & $2.0 \pm 1.10$ & $2.0 \pm 1.15$ & $2.0 \pm 1.15$ & $1.8 \pm 1.44$ & $1.8 \pm 1.11$ \\
\hline & & B. cereus & $3.3 \pm 0.18^{*}$ & $3.4 \pm 0.23^{*}$ & $3.2 \pm 0.25^{*}$ & $3.1 \pm 0.06^{*}$ & $3.1 \pm 0.09$ & $3.4 \pm 0.50^{*}$ & $2.9 \pm 0.41$ \\
\hline & \multirow[t]{5}{*}{$0.2 \%$} & $\angle A B$ monoculture & $2.5 \pm 0.34^{*}$ & $2.0 \pm 0.53^{*}$ & $2.2 \pm 0.46^{*}$ & $1.8 \pm 0.27^{*}$ & $2.2 \pm 0.38^{*}$ & $2.2 \pm 0.62^{*}$ & $1.2 \pm 0.25$ \\
\hline & & P. aeruginosa & $0.8 \pm 0.79$ & $1.0 \pm 0.76^{*}$ & $0.2 \pm 0.38$ & $0.1 \pm 0.88$ & $1.0 \pm 0.86^{*}$ & $1.0 \pm 0.88^{*}$ & $0.7 \pm 0.43$ \\
\hline & & S. aureus & $1.7 \pm 0.64^{*}$ & $1.6 \pm 0.47^{*}$ & $1.7 \pm 0.52^{*}$ & $1.7 \pm 0.66^{*}$ & $1.7 \pm 0.64^{*}$ & $1.6 \pm 0.54^{*}$ & $0.6 \pm 0.30$ \\
\hline & & E. coli & $0.5 \pm 0.68$ & $0.1 \pm 0.50$ & $0.4 \pm 0.37$ & $0.5 \pm 0.64^{*}$ & $0.6 \pm 0.80^{*}$ & $0.3 \pm 0.56$ & $0.2 \pm 0.62$ \\
\hline & & B. cereus & 0 & 0 & 0 & 0 & 0 & 0 & 0 \\
\hline \multirow[t]{10}{*}{$\Delta \Pi \mathrm{TA}$} & \multirow[t]{5}{*}{$2 \%$} & $\angle A B$ monoculture & $2.2 \pm 0.63^{*}$ & $1.5 \pm 0.43^{*}$ & $1.7 \pm 0.65^{*}$ & $2.3 \pm 0.87^{*}$ & $1.8 \pm 0.57^{*}$ & $1.3 \pm 0.23^{*}$ & $1.1 \pm 0.01$ \\
\hline & & $P$. aeruginosa & $0.3 \pm 0.12$ & $0.3 \pm 0.10$ & $0.3 \pm 0.09$ & $0.3 \pm 0.05$ & $0.3 \pm 0.07$ & $0.6 \pm 0.03^{*}$ & $0.3 \pm 0.04$ \\
\hline & & S. aureus & $1.1 \pm 0.21^{*}$ & $1.3 \pm 0.18^{*}$ & $1.5 \pm 0.65^{*}$ & $1.1 \pm 0.21^{*}$ & $1.1 \pm 0.21^{*}$ & $1.3 \pm 0.34^{*}$ & $0.5 \pm 0.02$ \\
\hline & & E. coli & $0.7 \pm 0.20$ & $0.5 \pm 0.15$ & $0.5 \pm 0.08$ & $0.6 \pm 0.09$ & $0.6 \pm 0.06$ & $0.6 \pm 0.06$ & $0.6 \pm 0.01$ \\
\hline & & B. cereus & $1.3 \pm 0.25^{*}$ & $1.3 \pm 0.31^{*}$ & $1.5 \pm 0.74^{*}$ & $1.3 \pm 0.21^{*}$ & $1.4 \pm 0.21^{*}$ & $1.4 \pm 0.76^{*}$ & $0.7 \pm 0.03$ \\
\hline & \multirow[t]{5}{*}{$0.2 \%$} & $\angle A B$ monoculture & $0.31 \pm 0.11$ & $0.30 \pm 0.10$ & $0.31 \pm 0.08$ & $0.30 \pm 0.05$ & $0.27 \pm 0.03$ & $0.25 \pm 0.05$ & $0.31 \pm 0.06$ \\
\hline & & P. aeruginosa & $0.03 \pm 0.01$ & $0.03 \pm 0.01$ & $0.05 \pm 0.02$ & $0.03 \pm 0.01$ & $0.02 \pm 0.01$ & $0.03 \pm 0.02$ & $0.01 \pm 0.02$ \\
\hline & & S. aureus & $0.05 \pm 0.01$ & $0.01 \pm 0.01$ & $0.05 \pm 0.01$ & $0.02 \pm 0.02$ & $0.05 \pm 0.03$ & $0.05 \pm 0.02$ & $0.02 \pm 0.01$ \\
\hline & & E. coli & $0.08 \pm 0.01$ & $0.50 \pm 0.01$ & $0.52 \pm 0.01$ & $0.5 \pm 0.02$ & $0.07 \pm 0.02$ & $0.23 \pm 0.02$ & $0.28 \pm 0.09$ \\
\hline & & B. cereus & $0.02 \pm 0.01$ & $0.05 \pm 0.01$ & $0.05 \pm 0.01$ & $0.03 \pm 0.01$ & $0.05 \pm 0.02$ & $0.05 \pm 0.01$ & $0.01 \pm 0.02$ \\
\hline
\end{tabular}

${ }^{\mp}$ Suspensions of $\mathrm{LAB}\left(10^{7} \mathrm{CFU} / \mathrm{mL}\right)$ in MRS broth without sorbic acid were added into the wells with 48-h old biofilms pre-formed by pathogenic bacteria and incubation was continued for the next $24 \mathrm{~h} . \Delta \mathrm{pH}$ and $\triangle T \mathrm{~A}$ were calculated as a difference between initial and final values. The Total Titratable Acidity (TTA) is expressed as $\mathrm{mL}$ of $0.1 \mathrm{M} \mathrm{NaOH}$ as required to achieve the final $\mathrm{pH}$ of 8.2

* denotes statistically significant difference with probiotic strain L. plantarum 8PA3 $(p<0.05)$ 
Table 3 The broth ${ }^{\ddagger}$ acidification rate in mixed cultures of novel LAB strains and pathogenic bacteria

\begin{tabular}{|c|c|c|c|c|c|c|c|c|c|}
\hline & Glucose & Strains & $\begin{array}{l}\text { L. plantarum } \\
\text { AG } 1\end{array}$ & $\begin{array}{l}\text { P. acidilactici } \\
\text { AG } 8\end{array}$ & $\begin{array}{l}\text { L. plantarum } \\
\text { AG } 9\end{array}$ & $\begin{array}{l}\text { L. plantarum } \\
\text { AG } 10\end{array}$ & $\begin{array}{l}\text { L. plantarum } \\
\text { AG } 15\end{array}$ & $\begin{array}{l}\text { L. fermentum } \\
\text { AG } 16\end{array}$ & $\begin{array}{l}\text { L. plantarum } \\
\text { 8PA3 }\end{array}$ \\
\hline \multirow[t]{10}{*}{$\Delta \mathrm{pH}$} & \multirow[t]{5}{*}{$2 \%$} & $\angle A B$ monoculture & $3.4 \pm 0.35^{*}$ & $3.2 \pm 0.24^{*}$ & $3.4 \pm 0.31^{*}$ & $3.6 \pm 0.56^{*}$ & $3.3 \pm 0.23^{*}$ & $3.2 \pm 0.11^{*}$ & $2.3 \pm 0.15$ \\
\hline & & P. aeruginosa & $0.5 \pm 0.27^{*}$ & $0.5 \pm 0.67^{*}$ & $0.6 \pm 0.35^{*}$ & $0.4 \pm 0.19^{*}$ & $0.5 \pm 0.5^{*}$ & $0.8 \pm 0.52^{*}$ & $-0.3 \pm 0.29$ \\
\hline & & S. aureus & $3.0 \pm 0.62$ & $3.0 \pm 0.50$ & $3.1 \pm 0.52$ & $3.0 \pm 0.62$ & $3.1 \pm 0.51$ & $3.1 \pm 0.62$ & $2.9 \pm 0.23$ \\
\hline & & E. coli & $2.6 \pm 0.66$ & $2.6 \pm 0.75$ & $2.6 \pm 0.72$ & $2.6 \pm 0.65$ & $2.6 \pm 0.64$ & $2.6 \pm 0.61$ & $2.3 \pm 0.68$ \\
\hline & & B. cereus & $3.6 \pm 0.06^{*}$ & $3.8 \pm 0.31^{*}$ & $3.7 \pm 0.53^{*}$ & $3.7 \pm 0.52^{*}$ & $3.7 \pm 0.67^{*}$ & $4.0 \pm 0.25^{*}$ & $2.9 \pm 1.53$ \\
\hline & \multirow[t]{5}{*}{$0.2 \%$} & $\angle A B$ monoculture & $3.5 \pm 0.34^{*}$ & $2.0 \pm 0.53^{*}$ & $2.2 \pm 0.46^{*}$ & $1.8 \pm 0.27^{*}$ & $2.2 \pm 0.38^{*}$ & $2.2 \pm 0.62^{*}$ & $1.2 \pm 0.25$ \\
\hline & & P. aeruginosa & $-0.3 \pm 0.16$ & $-0.3 \pm 0.15$ & $-0.3 \pm 0.02$ & $-0.2 \pm 0.01$ & $-0.3 \pm 0.13$ & $-0.2 \pm 0.37$ & $-0.3 \pm 0.11$ \\
\hline & & S. aureus & $1.2 \pm 0.28$ & $1.2 \pm 0.38$ & $1.3 \pm 0.17$ & $1.1 \pm 0.33$ & $1.3 \pm 0.05$ & $0.9 \pm 0.16$ & $1.2 \pm 0.28$ \\
\hline & & E. coli & $0.5 \pm 0.69$ & $0.3 \pm 0.42$ & $1.0 \pm 0.56$ & $0.6 \pm 1.16$ & $0.9 \pm 0.15$ & $0.3 \pm 0.37$ & $0.3 \pm 0.97$ \\
\hline & & B. cereus & 0 & 0 & 0 & 0 & 0 & 0 & 0 \\
\hline \multirow[t]{10}{*}{$\Delta \Pi \mathrm{A}$} & \multirow[t]{5}{*}{$2 \%$} & $\angle A B$ monoculture & $2.2 \pm 0.63^{*}$ & $1.5 \pm 0.43^{*}$ & $1.7 \pm 0.65^{*}$ & $2.3 \pm 0.87^{*}$ & $1.8 \pm 0.57^{*}$ & $1.3 \pm 0.23^{*}$ & $0.1 \pm 0.01$ \\
\hline & & P. aeruginosa & $0.9 \pm 0.12^{*}$ & $0.6 \pm 0.09$ & $0.8 \pm 0.08^{*}$ & $0.6 \pm 0.34$ & $0.7 \pm 0.37^{*}$ & $0.7 \pm 0.36^{*}$ & $0.1 \pm 0.02$ \\
\hline & & S. aureus & $1.1 \pm 0.23$ & $1.3 \pm 0.16$ & $1.5 \pm 0.31$ & $0.8 \pm 0.42$ & $1.4 \pm 0.48$ & $1.1 \pm 0.39$ & $1.5 \pm 0.15$ \\
\hline & & E. coli & $1.3 \pm 0.22^{*}$ & $1.0 \pm 0.11$ & $1.1 \pm 0.13$ & $1.3 \pm 0.61^{*}$ & $1.9 \pm 0.13^{*}$ & $1.5 \pm 0.35$ & $0.8 \pm 0.13$ \\
\hline & & B. cereus & $1.7 \pm 0.41^{*}$ & $1.5 \pm 0.21$ & $2.0 \pm 0.56^{*}$ & $1.7 \pm 0.24^{*}$ & $1.8 \pm 0.28^{*}$ & $2.0 \pm 0.29^{*}$ & $1.0 \pm 0.08$ \\
\hline & \multirow[t]{5}{*}{$0.2 \%$} & $\angle A B$ monoculture & $0.31 \pm 0.11$ & $0.27 \pm 0.10$ & $0.30 \pm 0.02$ & $0.32 \pm 0.05$ & $0.27 \pm 0.03$ & $0.25 \pm 0.05$ & $0.31 \pm 0.06$ \\
\hline & & P. aeruginosa & $0.04 \pm 0.02$ & $0.04 \pm 0.02$ & $0.01 \pm 0.01$ & $0.01 \pm 0.01$ & $0.04 \pm 0.02$ & $0.04 \pm 0.02$ & $0.04 \pm 0.02$ \\
\hline & & S. aureus & $0.00 \pm 0.01$ & $0.00 \pm 0.01$ & $0.00 \pm 0.01$ & $0.00 \pm 0.01$ & $0.00 \pm 0.01$ & $0.00 \pm 0.01$ & $0.05 \pm 0.01$ \\
\hline & & E. coli & $0.05 \pm 0.01$ & $0.00 \pm 0.01$ & $0.11 \pm 0.01$ & $0.05 \pm 0.01$ & $0.05 \pm 0.01$ & $0.00 \pm 0.01$ & $0.05 \pm 0.01$ \\
\hline & & B. cereus & $0.31 \pm 0.05$ & $0.30 \pm 0.05$ & $0.31 \pm 0.04$ & $0.30 \pm 0.05$ & $0.31 \pm 0.05$ & $0.31 \pm 0.05$ & $0.29 \pm 0.05$ \\
\hline
\end{tabular}

${ }^{\mp}$ Mixed suspensions of LAB and pathogenic bacteria (10 $7 \mathrm{CFU} / \mathrm{mL}$ each) in MRS broth without sorbic acid were grown for $48 \mathrm{~h}$. $\Delta \mathrm{pH}$ and $\triangle T \mathrm{TA}$ were calculated as a difference between initial and final values. Total Titratable Acidity (TTA) is expressed as $\mathrm{mL}$ of $0.1 \mathrm{M} \mathrm{NaOH}$ needed to achieve the final pH of 8.2

* denotes statistically significant difference with probiotic strain L. plantarum 8PA3 $(p<0.05)$

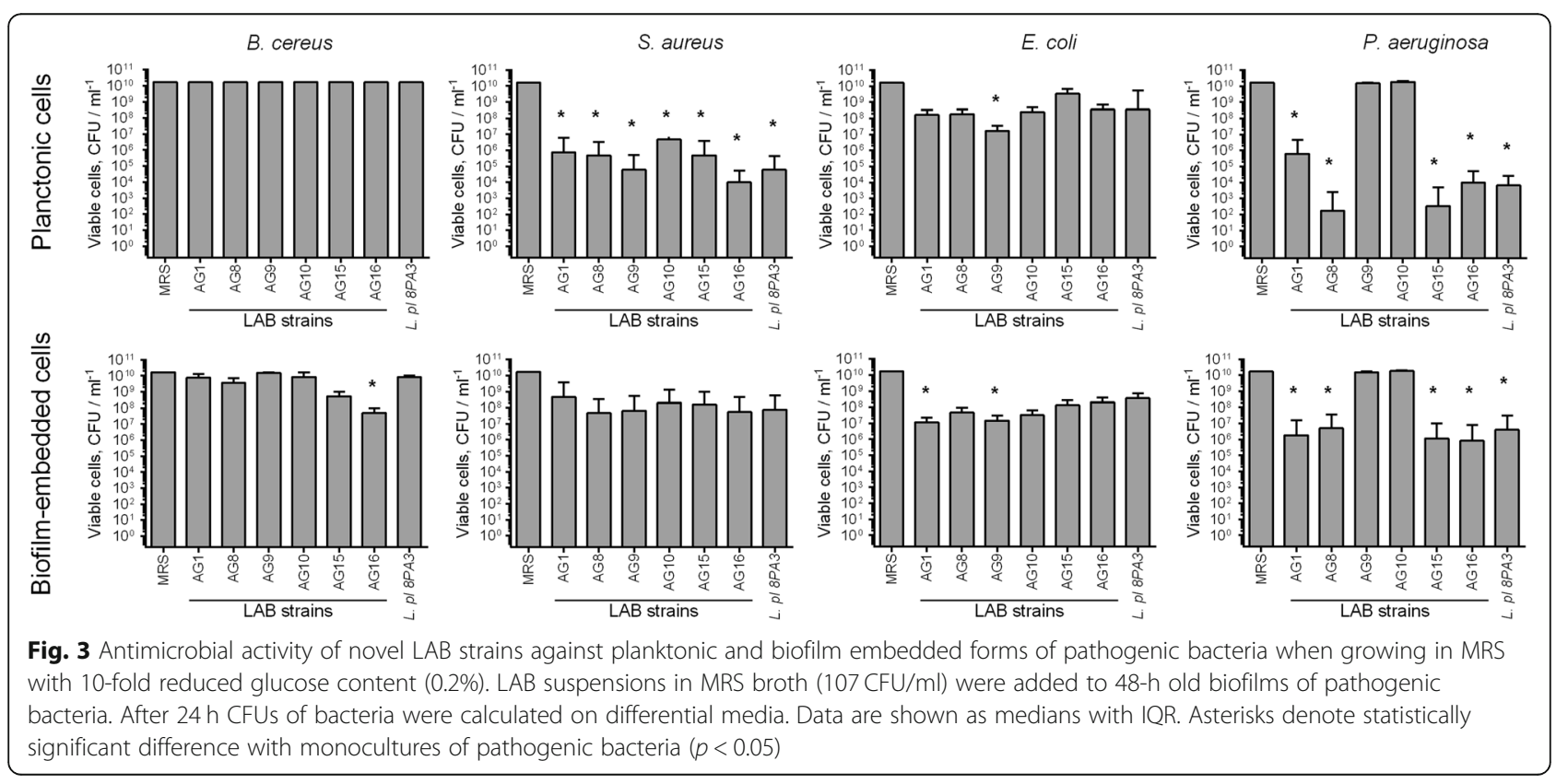


cultures (Table 3) while viable LAB were identified in both culture liquid and biofilm, although the growth of AG8, AG15 and AG16 has been significantly repressed. Interestingly, no repression of AG9 and AG10 could be observed suggesting that $P$. aeruginosa did not repress their growth while neutralized the acid produced by them.

Next, to check the significance of the acidification contribution to the antibacterial activity of LAB isolates, their antibacterial activity has been studied when growing in MRS with reduced amount of glucose $(0.2 \%)$, which is the main substrate for the lactate production. Due to the lowered acidification rate in MRS containing $0.2 \%$ glucose in comparison with broth supplemented with $2 \%$ glucose (see Table 2), the antibacterial activity of LAB decreased (Fig. 3), while the cultures reached similar CFUs densities like in the full broth (compare Additional file 1: Fig. S1 and S3). These data suggest that the broth acidification seems to be the dominating antagonistic factor of both newly isolated and reference LAB strains. In contrast, strains AG8 and AG15 repressed the spreading of $P$. aeruginosa into the culture liquid from the biofilm independently of the glucose content (compare Figs. 1 and 3), although exhibiting slightly lower efficacy in low-glucose medium, suggesting the potential involvement of other antagonistic factors by these strains such as bacteriocines or hydrogen peroxide. When both LAB and pathogens were inoculated simultaneously in MRS containing $0.2 \%$ glucose, significant repression of only $S$. aureus growth could be observed (Fig. 4), most likely, due to low acidification rate (See Table 3).

\section{Strains identification}

All six isolates demonstrated better growth capabilities at $37^{\circ} \mathrm{C}$ compared to $30^{\circ} \mathrm{C}$, while remained capable of growing at temperatures up to $45^{\circ} \mathrm{C}$, were $\mathrm{Gram}$ positive and catalase-negative. Five of them were rodshaped and based on the 16S rRNA gene sequence were identified as Lactobacillus plantarum (AG1, AG9, AG10 and AG15, 99\% identity) and Lactobacillus fermentum (AG8, AG16, 99\% identity). At the same time the comparison of 16S rRNA genes of isolates among themselves did not reveal $100 \%$ identity, suggesting these isolates as different strains in agreement with antibacterial activity data.

\section{Tolerances to acid and bile}

The ability to survive under gastric conditions including low $\mathrm{pH}$ and bile presence is an important property of LAB strains used in the food industry while it is strongly species- and strain- dependent. The tolerance of isolates was investigated by exposing cells to gastric-simulated conditions ( $\mathrm{pH} 2.0,1 \%$ bile) for $2 \mathrm{~h}$. Isolates AG8, AG9, AG10 and AG15 demonstrated remarkable resistance with the growth reduction by 4-8 times in comparison with the reference L. plantarum strain (Table 4). AG10 strain appeared the most resistant one so far.

\section{Adhesion capacity}

Percentages of autoaggregation after 4 and $24 \mathrm{~h}$ of incubation at $37^{\circ} \mathrm{C}$ and cell surface hydrophobicity are summarized in Table 4. None of the strains demonstrated high hydrophobicity measured as their ability to adhere to hexadecane, while strains AG9, AG10 and AG16 showed medium hydrophobicity in comparison with

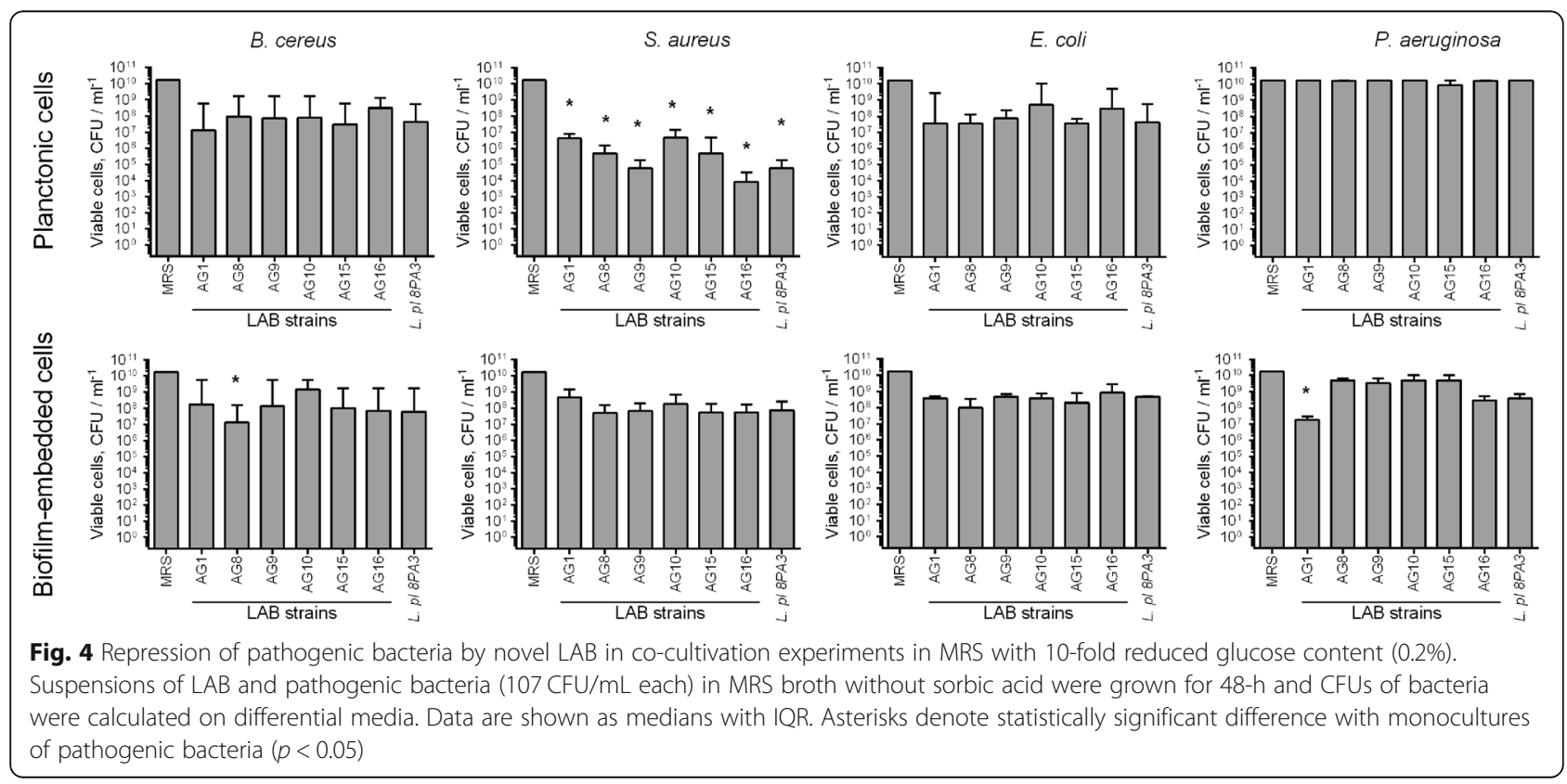


Table 4 Characterization of probiotic properties of novel LAB strains isolated from silage

\begin{tabular}{|c|c|c|c|c|c|c|}
\hline \multirow[t]{2}{*}{ LAB species } & \multirow[t]{2}{*}{ Strain } & \multirow{2}{*}{$\begin{array}{l}\text { Survival } \\
\text { rate, } \%\end{array}$} & \multicolumn{2}{|c|}{ Hydrophobicity } & \multicolumn{2}{|c|}{ Auto-aggregation, \% } \\
\hline & & & $\%^{a}$ & Grade $^{b}$ & $4 \mathrm{~h}$ & $24 \mathrm{~h}$ \\
\hline L. plantarum & $A G 1$ & $6.0 \pm 3.70$ & $18.4 \pm 2.40$ & $\mathrm{~L}$ & $26.8 \pm 4.63$ & $90.3 \pm 7.83$ \\
\hline P. acidilactici & AG8 & $13.1 \pm 1.47$ & $24.4 \pm 2.00$ & L & $26.0 \pm 5.86$ & $79.6 \pm 8.98$ \\
\hline L. plantarum & AG9 & $11.4 \pm 0.60$ & $55.6 \pm 1.71$ & M & $35.6 \pm 3.04$ & $88.7 \pm 5.28$ \\
\hline L. plantarum & AG10 & $26.0 \pm 0.14$ & $65.7 \pm 7.52$ & M & $21.7 \pm 7.00$ & $66.6 \pm 7.44$ \\
\hline L. plantarum & AG15 & $25.9 \pm 0.70$ & $3.2 \pm 0.42$ & $\mathrm{~L}$ & $25.1 \pm 6.52$ & $78.5 \pm 7.26$ \\
\hline L. fermentum & AG16 & $3.5 \pm 0.54$ & $41.2 \pm 5.06$ & M & $26.4 \pm 4.18$ & $85.5 \pm 5.40$ \\
\hline L. plantarum & 8PA3 & $8.2 \pm 0.92$ & $23.2 \pm 1.03$ & L & $23.1 \pm 4.23$ & $72.7 \pm 8.35$ \\
\hline
\end{tabular}

a Percentage of hydrophobicity

${ }^{\mathrm{b}}$ Strains were classified as low (L) or medium (M) according to their hydrophobicity capacities according to [44]

other isolates and with the reference strain. After $4 \mathrm{~h}$ of incubation similar percentage of autoaggregation ranging from 21 to $27 \%$ was observed for all isolates with the exception of the AG9 strain (36\% of autoaggregation). After $24 \mathrm{~h}$ low autoaggregation was detected for the strains AG8, AG10 and AG15, while for the strains AG1, AG9 and AG16 about $90 \%$ of autoaggregation could be observed.

\section{Antibiotic resistance}

Table 5 summarizes the LAB isolates resistance against conventional antibiotics. In general, all LAB strains were resistant to streptomycin, aminoglycosides, vancomycin and ciprofloxacin. Taking into account high similarities in resistance patterns, we hypothesize that the tolerance to antimicrobials is governed rather by phenotypic resistance than by the presence of particular resistance genes and thus is likely non-transmissible.

Table 5 Antibiotic resistance of newly isolated $L A B$ strains from silage (diameters of inhibition zones, $\mathrm{mm}$ )

\begin{tabular}{|c|c|c|c|c|c|c|c|}
\hline \multirow[t]{2}{*}{ Antibiotics } & \multirow{2}{*}{$\begin{array}{l}\text { Amount } \\
\text { per disc, } \\
\mu \mathrm{g}\end{array}$} & \multicolumn{6}{|c|}{ LAB strains } \\
\hline & & AG1 & AG8 & AG9 & AG10 & AG15 & AG16 \\
\hline Ampicillin & 10 & $26(S)$ & $18(S)$ & $20(S)$ & $19(\mathrm{~S})$ & $20(S)$ & $17(S)$ \\
\hline Amikacin & 30 & $12(\mathrm{R})$ & $16(l)$ & $9(\mathrm{R})$ & $10(\mathrm{R})$ & $3(\mathrm{R})$ & $8(\mathrm{R})$ \\
\hline Chloramphenicol & 30 & $22(\mathrm{~S})$ & $25(\mathrm{~S})$ & $28(S)$ & $23(\mathrm{~S})$ & $22(S)$ & $29(S)$ \\
\hline Ciprofloxacin & 5 & $0(\mathrm{R})$ & $0(R)$ & $O(R)$ & $O(R)$ & $O(R)$ & $9(\mathrm{R})$ \\
\hline Clindamycin & 2 & $16(S)$ & $15(S)$ & $33(S)$ & $18(S)$ & $28(\mathrm{~S})$ & $24(S)$ \\
\hline Erythromycin & 15 & $20(S)$ & $20(S)$ & $26(S)$ & $22(\mathrm{~S})$ & $20(S)$ & $26(S)$ \\
\hline Gentamicin & 10 & $10(\mathrm{R})$ & $11(\mathrm{R})$ & $10(\mathrm{R})$ & $9(\mathrm{R})$ & $0(R)$ & $13(S)$ \\
\hline Kanamycin & 30 & $O(R)$ & $0(\mathrm{R})$ & $6(\mathrm{R})$ & $0(\mathrm{R})$ & $O(R)$ & $5(\mathrm{R})$ \\
\hline Rifampicin & 5 & $20(S)$ & $26(S)$ & $20(S)$ & $20(S)$ & $13(\mathrm{R})$ & $30(S)$ \\
\hline Streptomycin & 30 & $10(\mathrm{R})$ & $14(I)$ & $8(\mathrm{R})$ & $11(\mathrm{R})$ & $11(\mathrm{R})$ & $11(\mathrm{R})$ \\
\hline Tetracycline & 30 & $20(S)$ & $20(S)$ & $20(S)$ & $21(\mathrm{~S})$ & $19(\mathrm{~S})$ & $25(S)$ \\
\hline Vancomycin & 30 & $0(\mathrm{R})$ & $O(R)$ & $6(R)$ & $14(\mathrm{R})$ & $0(R)$ & $2(\mathrm{R})$ \\
\hline
\end{tabular}

Inhibition zones $(\mathrm{mm})$ (means \pm SD of 3 trials) were interpreted as susceptible $(\mathrm{S})$, intermediate $(\mathrm{I})$, or resistant $(\mathrm{R})$ according to [45]
Fermentation properties of selected LAB strains in skimmed milk

All six newly isolated LAB successfully demonstrated their ability of skimmed milk fermentation (Table 6). In general, the keynote properties of the products obtained by these strains were comparable with the yoghurt obtained by using L. bulgaricus and S. thermophilus mixture as a starter culture. In particular, the contents of total protein, whey protein and lactose were comparable in all obtained products. The fat concentration remained unchanged during the fermentation and remained at $0.2 \%$. While in all cases $\mathrm{pH}$ dropped from 6.7 to 3.6-3.9, the highest acidification rate was observed for the AG8 and AG10 strains (Table 6), which also exhibited pronounced antibacterial activity (see Table 1 and Fig. 1). Moreover, these two strains provided the lowest syneresis in products $(19 \%)$ that is significantly lower than in the classical yoghurt. Furthermore, the water hold capacity (WHC) of the products obtained with AG8, AG10 and AG15 strains was similar to that of the classical yoghurt. These data allows suggesting these strains as perspective cultures for co-introduction into LAB precultures for milk fermentation. In marked contrast, using AG1, AG9 and AG16 strains resulted in products with lower WHC and higher syneresis suggesting lower quality of the final product.

\section{Discussion}

In this work we report the newly isolated LAB strains from clover silage exhibiting antibacterial activity as well as attractive probiotic and milk-fermenting properties. We particularly aim to identify bacterial strains with high antibacterial activity against biofilm-embedded pathogens as they often exhibit pronounced resistance against conventional antimicrobials and thus possess a serious threat for the food industry where the use of biocides is strictly limited. In contrast, being used either as new starter cultures for the milk fermentation or as minor additive components to the classical cultures, LAB strains characterized by significant antagonism 
Table 6 Properties of fermented skimmed milk

\begin{tabular}{llllllllll}
\hline Strain & $\begin{array}{l}\text { Protein, } \\
\%\end{array}$ & $\begin{array}{l}\text { Whey protein, } \\
\%\end{array}$ & $\begin{array}{l}\text { Lactose, } \\
\%\end{array}$ & Solids, $\%$ & $\mathrm{pH}$ & TTA. ml & $\begin{array}{l}\text { WHC }, \% \\
\text { \% }\end{array}$ & $\begin{array}{l}\text { Syneresis, g water/100 g } \\
\text { yoghurt }\end{array}$ & $\begin{array}{l}\text { Dynamic viscosity, } \\
\text { sec }\end{array}$ \\
\hline AG1 & $4.1 \pm 0.08$ & $3.0 \pm 0.11$ & $4.5 \pm 0.07$ & $8.8 \pm 0.11$ & $3.7 \pm 0.08$ & $1.0 \pm 0.01$ & $36 \pm 4.2$ & $22 \pm 2.9$ & $6.6 \pm 0.17$ \\
AG8 & $4.2 \pm 0.10$ & $3.1 \pm 0.08$ & $4.5 \pm 0.11$ & $9.4 \pm 0.14$ & $3.7 \pm 0.08$ & $1.1 \pm 0.02$ & $37 \pm 1.60$ & $19 \pm 1.5$ & $7.1 \pm 0.09$ \\
AG9 & $4.2 \pm 0.08$ & $3.0 \pm 0.11$ & $4.5 \pm 0.08$ & $9.4 \pm 0.20$ & $3.7 \pm 0.20$ & $1.0 \pm 0.02$ & $35 \pm 2.88$ & $24 \pm 3.5$ & $7.8 \pm 0.28$ \\
AG10 & $4.1 \pm 0.08$ & $3.1 \pm 0.08$ & $4.6 \pm 0.04$ & $9.5 \pm 0.17$ & $3.6 \pm 0.08$ & $1.1 \pm 0.02$ & $36 \pm 2.88$ & $19 \pm 4.2$ & $7.1 \pm 0.17$ \\
AG15 & $4.1 \pm 0.10$ & $3.1 \pm 0.06$ & $4.4 \pm 0.14$ & $9.7 \pm 0.07$ & $3.9 \pm 0.13$ & $1.0 \pm 0.02$ & $37 \pm 3.48$ & $24 \pm 3.1$ & $6.0 \pm 0.22$ \\
AG16 & $4.2 \pm 0.10$ & $3.0 \pm 0.06$ & $4.5 \pm 0.10$ & $9.1 \pm 0.09$ & $3.9 \pm 0.08$ & $1.0 \pm 0.01$ & $34 \pm 2.11$ & $24 \pm 2.1$ & $6.6 \pm 0.11$ \\
Yogurt & $4.2 \pm 0.22$ & $3.1 \pm 0.04$ & $4.5 \pm 0.11$ & $11.1 \pm 0.11$ & $3.9 \pm 0.21$ & $0.9 \pm 0.02$ & $39 \pm 3.48$ & $23 \pm 3.5$ & $7.2 \pm 0.17$ \\
Milk & $4.2 \pm 0.09-$ & $4.7 \pm 0.08$ & $8.7 \pm 0.173$ & $6.7 \pm 0.10$ & $0.2 \pm 0.01$ & - & - & -
\end{tabular}

${ }^{a}$ WHC Water holding capacity

against biofilm-embedded pathogenic bacteria could prevent product contamination in the first place thus reducing the need in often highly toxic biocides that is altogether in line with the development of green food technologies.

During the initial screening, six strains with the highest antimicrobial activity have been selected (Table 1), and five of them (excepting AG15) were able to efficiently eradicate the biofilms of pathogenic $S$. aureus and $E$. coli and prevent their spreading from the biofilm by either being added to preformed biofilms or prevent the growth of bacteria in co-cultivation experiments (Figs. 1 and 2). While no repression of $P$. aeruginosa could be observed during co-cultivation, AG8, AG10 and AG16 strains, identified as L. plantarum and L. fermentum, were able to eradicate this pathogen in the biofilm almost completely and repress to a certain extent its spreading from the biofilm into the culture liquid (Fig. 1). Moreover, in co-cultivation experiments AG16 also repressed the biofilm formation and the growth of $B$. cereus (Fig. 2) being thereby an attractive tool for the prevention of food contamination by this pathogen, which forms the biofilm with high resistance to many conventional antimicrobials [46].

The base of antimicrobial activities of these strains is likely linked with the acidification of the growth media, since the reduction of glucose from 2 to $0.2 \%$ with consequent drastic decrease of acidification rate (Table 3 ) led to significantly reduced antagonistic properties of the strains (Fig. 3). Therefore the absence of the P. aeruginosa growth repression in co-cultivation experiments could be assumed as a consequence of no broth acidification in the mixed culture (Table 2). Of note, the activity of AG8 and AG15 strains against $P$. aeruginosa biofilms did not depend of glucose content, suggesting the production of other antagonistic factors by these strains, possibly, bacteriocines or hydrogen peroxide.

The investigations of other probiotic properties of the novel LAB isolates revealed that the strain AG10 exhibits the best characteristics. It demonstrated the highest hydrophobicity on hexadecane (66\%), medium auto-aggregation rate $(67 \%$ in $24 \mathrm{~h})$ and appeared the most resistant to simulated gastric conditions (Table 4) among all tested strains. Since the hydrophobicity and autoaggregation properties are believed to be associated with the adhesion of LAB to epithelial cells in human intestine that is required for their probiotic properties [47, 48] and the hydrophobicity against hexadecane has been reported to be within the range of $5-50 \%$, our data suggests pronounced adhesion properties of the AG10 strain. Moreover, the milk fermented by AG10 was characterized by low syneresis, high WHC and highest acidification (Table 6). These data allows suggesting Lactobacillus plantarum AG10 strain as a potential starter culture and/or functional component for the production of fermented milk and yoghurt additionally characterized by pronounced anti-biofilm properties.

\section{Conclusion}

Among the six novel LAB strains isolated from the silage and exhibiting high acidification rate and pronounced antagonism with various both planktonic and biofilmembedded foodborne pathogenic bacteria, the Lactobacillus plantarum strain AG10 demonstrated beneficial probiotic and milk fermentation properties while remaining resistant to simulated gastric conditions. AG10 efficiently eradicates biofilms of foodborne pathogens including $S$. aureus, E. coli and P. aeruginosa and prevents spreading of pathogens from the biofilm, as well as demonstrates attractive probiotic properties. These data allows suggesting this strain as perspective starter culture and/or functional component for the fermented milk.

\section{Methods}

\section{Isolation of $\mathrm{LAB}$ and growth conditions}

Lactic acid bacteria were isolated from 5-month fermented silage ("Zavolzh'e", Kaibitsy district, Republic of Tatarstan, Russia). Silage samples $(10 \mathrm{~g})$ were blended with $50 \mathrm{ml}$ of sterile saline $(0.9 \% \mathrm{NaCl})$ and after 
intensive shaking a series of 10 -fold dilutions in saline were prepared $\left(10^{-1}-10^{-8}\right)$. Each dilution $(1 \mathrm{ml})$ was mixed with $20 \mathrm{ml}$ of cabbage agar (CA) (cabbage $200 \mathrm{~g}$, glucose $20 \mathrm{~g}$, peptone $10 \mathrm{~g}$, agar $20 \mathrm{~g}$, water $1000 \mathrm{ml}$ ) containing 3\% $\mathrm{CaCO} 3$ and plated. The plates were incubated under microaerophilic conditions at $37^{\circ} \mathrm{C}$ for $48 \mathrm{~h}$. The bacterial colonies forming clear zones of $\mathrm{CaCO}_{3}$ hydrolysis were considered as putative LAB and were individually picked and streaked on de Man, Rogosa and Sharpe (MRS) agar (HiMedia, India) plates by dilution streaking. The plates were incubated under microaerophilic conditions at $37^{\circ} \mathrm{C}$ until the single colonies were obtained; these isolates were then subjected to Gram staining and catalase test. Only catalase-negative and Gram-positive isolates were selected for further studies. Bacterial isolates were maintained on solid MRS agar for immediate use or in $50 \%$ glycerol at $-80^{\circ} \mathrm{C}$.

\section{Reference probiotic $L A B$ and pathogenic bacteria} Lactobacillus plantarum 8PA3 approved as a probiotic strain (Biomed, Russia) was used as a reference [49]. A mixture of Streptococcus thermophilus and Lactobacillus delbrueckii ssp. bulgaricus (CFUs ratio 1:1) was used as a reference classic yoghurt starter (Yoghurtel, Russia). Escherichia coli MG1655 (K-12), Staphylococcus aureus ssp. aureus ATCC 29213, Klebsiella pneumonia (clinical isolate), Pseudomonas aeruginosa ATCC 27853, and Bacillus cereus (clinical isolate) were used in this study as test bacteria when evaluating the antibacterial activity of LAB. Clinical isolates of $B$. cereus and $K$. pneumoniae were kindly provided by Kazan Institute of Epidemiology and Microbiology (Kazan, Russia) and by the Institute of Medical Microbiology (Giessen, Germany), respectively.

\section{Antibacterial activity}

Antagonistic activity was examined by agar spot test described in [50]. Briefly, overnight cultures of individual strains were spotted $(2 \mu \mathrm{l})$ on the surface of MRS agar and incubated anaerobically (Anaerogas gaspack, NIKI MLT, Russia) for $24 \mathrm{~h}$ at $37^{\circ} \mathrm{C}$ to develop the spots. A $100-\mu \mathrm{l}$ volume of an overnight culture of test bacteria was mixed with $7 \mathrm{ml}$ of soft Luria-Bertani (LB) agar $(0.7 \%)$, poured over the plate and plates were incubated aerobically at $37^{\circ} \mathrm{C}$. After $24 \mathrm{~h}$ of incubation, zones of bacterial growth inhibition were measured from the edge of the colony to the edge of the inhibition zone. The inhibitory effect of MRS was used as negative control. Each test was performed in triplicate.

Additionally, the antagonism of LAB strains was tested against pathogens embedded into the biofilm. For that, 48-h old biofilms of pathogenic bacteria were grown on 24-well polystirol plates in BM broth [51-53], washed with sterile saline $(0.9 \% \mathrm{NaCl})$ and wells were filled with MRS broth without sorbic acid containing $10^{7} \mathrm{CFU} / \mathrm{ml}$ of LAB isolates (diluted 24-h old culture); L. plantarum 8PA3 was used as a reference strain. As a control, a cellfree MRS broth was used. CFUs were counted by using the drop-plate assay [54] with modifications [53, 55]. After $24 \mathrm{~h}, 10$-fold dilution series of culture liquid and the suspended biofilm were prepared and plated on differential media by drops ( $5 \mu \mathrm{L}$ each). LAB were plated onto MRS agar, mannitol-salt agar (Sigma) was used for S. aureus, Endo agar (Sigma) was used for E. coli, cetrimide agar (Sigma) was used for $P$. aeruginosa. B. cereus cells were seeded on LB agar and bigger colonies with rough surfaces have been considered as $B$. cereus. CFUs were counted from the two last drops typically containing 5-15 colonies. Data from 5 independent experiments were presented as medians with IQR.

\section{Acidification rate}

The acidification rate of the strains was evaluated by measuring $\mathrm{pH}$ and Total Titratable Acidity (TTA) of the culture liquid after $24 \mathrm{~h}$ growth in MRS broth. An overnight culture $(1 \% \mathrm{v} / \mathrm{v})$ of each LAB strain was individually inoculated into $5 \mathrm{ml}$ of MRS broth and incubated for $24 \mathrm{~h}$ at $37^{\circ} \mathrm{C}$. Then the $\mathrm{pH}$ and TTA of the culture liquid were measured. To determine TTA, the cell-free supernatant $(1 \mathrm{~mL})$ was titrated with $0.1 \mathrm{M} \mathrm{NaOH}$ to a final $\mathrm{pH}$ of 8.2 , detected by phenolphthalein; TTA was expressed as $\mathrm{mL}$ of $0.1 \mathrm{M} \mathrm{NaOH}$ needed to achieve the final $\mathrm{pH}$ of 8.2. The cell-free broth incubated together with other samples served as a reference.

\section{Tolerance to simulated human GI tract (acid and bile tolerance)}

Synthetic gastric fluid was prepared by suspending $8.3 \mathrm{~g}$ of proteose peptone, $3.5 \mathrm{~g}$ D-glucose, $2.05 \mathrm{~g} \mathrm{NaCl}, 0.6 \mathrm{~g}$ $\mathrm{KH}_{2} \mathrm{PO}_{4}, 0.11 \mathrm{~g} \mathrm{CaCl}_{2}, 0.37 \mathrm{~g} \mathrm{KCl}, 0.05 \mathrm{~g}$ bile, $0.1 \mathrm{~g}$ lysozyme, $13.3 \mathrm{mg}$ pepsin in $100 \mathrm{ml}$ sterile distilled water. $\mathrm{pH}$ value was adjusted to 2.5 with $1 \mathrm{~N} \mathrm{HCl}$ [56]. Overnight LAB cultures were harvested by centrifugation and washed twice with physiological saline. Cell suspensions were adjusted to $\mathrm{OD}_{600}$ of 0.5 and treated with synthetic gastric fluid at $37^{\circ} \mathrm{C}$ for $1 \mathrm{~h}$. As a control, cells were incubated in physiological saline at $37^{\circ} \mathrm{C}$ for $1 \mathrm{~h}$. After the incubations, the cells were washed twice with physiological saline by centrifugation, stained with $2.5 \mu \mathrm{g} / \mathrm{ml}$ propidium iodide (PI) (Sigma-Aldrich) and analyzed by flow cytometry using a BD FACS Canto II (USA) flow cytometer. PI enables staining of non-viable cells. Data were obtained using FACS Diva software. Survival rate (\%) was calculated as: $\mathrm{N}_{1} / \mathrm{N}_{0} \times 100$, where $\mathrm{N}_{1}$ represents the count of cells non-stained with PI in test sample and $\mathrm{N}_{0}$ represents the total count of cells nonstained with PI in the control sample. 


\section{Cell surface hydrophobicity}

The bacterial adhesion to hexadecane was measured as described in [57]. The bacterial cells grown in the MRS broth at $37^{\circ} \mathrm{C}$ for $18 \mathrm{~h}$ were centrifuged, the cell pellet was washed twice with $0.1 \mathrm{M} \mathrm{KNO}_{3}(\mathrm{pH} 6.2)$ following by its resuspension in the same solution to an optical density of 0.4 at $400 \mathrm{~nm}\left(\mathrm{~A}_{0}\right)$. Bacterial cell suspensions $(2.4 \mathrm{ml})$ and $\mathrm{n}$-hexadecane $(0.4 \mathrm{ml})$ were mixed by vortexing and incubated at $37^{\circ} \mathrm{C}$ for $15 \mathrm{~min}$ for a complete phase separation in the mixture. The aqueous phase was gently taken out to measure its absorbance at $400 \mathrm{~nm}$ $\left(\mathrm{A}_{1}\right)$. The surface hydrophobicity (\%) was calculated as $\left(1-A_{1} / A_{0}\right) \times 100$. Strains were classified as low $(L)$ or medium $(\mathrm{M})$ according to their hydrophobicity capacities [44].

\section{Autoaggregation}

Autoaggregation ability of the isolates was tested following the methodology described in [58]. Briefly, the bacterial cells grown in MRS broth at $37^{\circ} \mathrm{C}$ for $18 \mathrm{~h}$ were centrifuged, the cell pellet was washed twice with PBS and then resuspended in PBS to an optical density of 0.5 at $600 \mathrm{~nm}\left(\mathrm{~A}_{0}\right)$. Bacterial cell suspensions $(4 \mathrm{ml})$ were incubated at $37^{\circ} \mathrm{C}$ in tubes for 4 or $24 \mathrm{~h}$ without shaking. The aqueous phase was gently taken out to measure its absorbance at $600 \mathrm{~nm}\left(\mathrm{~A}_{1}\right)$. Autoaggregation percentage was calculated as $\left(1-A_{1} / A_{0}\right) \times 100$.

\section{Resistance to antibiotics}

Antibiotic susceptibility of the LAB isolates was determined by disc diffusion method, as described earlier [59]. Briefly, bacteria were grown in MRS broth overnight at $37^{\circ} \mathrm{C}$ in anaerobic conditions (Anaerogas gaspack, NIKI MLT, Russia), and pour-plated on MRS agar plates. Antibiotic discs (Scientific Research Centre of Pharmacotherapy, Russia) were placed on the surface of inoculated plates. All isolates were screened for their susceptibility to ampicillin $(10 \mu \mathrm{g})$, amikacin $(30 \mu \mathrm{g})$, vancomycin $(30 \mu \mathrm{g})$, gentamicin $(10 \mu \mathrm{g})$, kanamycin $(30 \mu \mathrm{g})$, clindamycin $(2 \mu \mathrm{g})$, rifampicin $(5 \mu \mathrm{g})$, streptomycin $(30 \mu \mathrm{g})$, tetracycline $(30 \mu \mathrm{g})$, erythromycin $(15 \mu \mathrm{g})$, ciprofloxacin $(5 \mu \mathrm{g})$, chloramphenicol $(30 \mu \mathrm{g})$. After $48 \mathrm{~h}$ incubation in anaerobic conditions at $37^{\circ} \mathrm{C}$, the diameter of the inhibition zone was measured and interpreted as susceptible (S), intermediate (I), or resistant (R) according to [45]. For ampicillin $(\leq 16 \mathrm{~mm})$ and rifampicin $(\leq 16 \mathrm{~mm})$, breakpoints recommended for Enterococcus spp. were used [60].

\section{Genomic DNA isolation}

Genomic DNA was isolated from cells grown at $37^{\circ} \mathrm{C}$ for $16-18 \mathrm{~h}$ in MRS broth. Cells were harvested from 10 $\mathrm{ml}$ of culture liquid by centrifugation followed by resuspension in $1 \mathrm{ml}$ of $50 \mathrm{mM}$ Tris- $\mathrm{HCl}$ buffer ( $\mathrm{pH} 8.0$ ) containing lysozyme $(3 \mathrm{mg} / \mathrm{ml})$. After $2 \mathrm{~h}$ incubation at $37^{\circ} \mathrm{C}$, SDS was added until the final concentration of $1 \%$ was reached. After lysis of cells, $0.5 \mathrm{ml}$ of phenolchloroform mix was added and after intensive vortexing the mixture was separated by centrifugation at 14000 rpm for $5 \mathrm{~min}$. This step was repeated for three times. $0.7 \mathrm{ml}$ of upper fraction was mixed with $1 \mathrm{ml}$ of propanol-2 and precipitated DNA was collected, washed by ethanol and dissolved in pure water.

\section{Identification of LAB isolates}

The PCR reaction was carried out in a total volume of $25 \mu$ by using universal $16 \mathrm{~S}$ rRNA bacterial primers $27 \mathrm{~F}$ (5'-GAGTTTGATCCTGGCTCAG-3') and 1392R (5' ACGGTTACCTTGTTACGACTT-3') as offered by [61] and successfully used in [62,63]. The DNA fragments were purified from the agarose gel after electrophoresis and sequenced on an ABI Prism 3730 sequencer (Applied Biosystems). For species identification, sequences were aligned with NCBI database using BLAST algorithm (https://www.ncbi.nlm.nih.gov/BLAST/).

\section{Experimentally fermented skimmed milk}

Six selected strains that demonstrated promising properties during preliminary screening were used for experimental milk fermentation. To determine the fermentation capacity, pre-cultures of LAB were prepared by incubation at $40^{\circ} \mathrm{C}$ for $16 \mathrm{~h}$ in skimmed milk obtained by raw cow's milk pasteurization at $80^{\circ} \mathrm{C}$ for $30 \mathrm{~min}$ followed by final centrifugation at $3000 \mathrm{~g}$ for 10 min. Obtained pre-cultures were inoculated $(5 \% \mathrm{v} / \mathrm{v})$ into the milk and incubated at $40^{\circ} \mathrm{C}$ for $6 \mathrm{~h}$ followed by cooling for $24 \mathrm{~h}$ at $4{ }^{\circ} \mathrm{C}$. In the following, a series of properties of the fermented milk have been analyzed.

\section{Quantitative chemical analysis of fermented skimmed milk}

Analysis of protein, lactose and solids contents in the yogurt was performed on the InfraLUM ${ }^{\circ}$ FT-12 (Russian Federation) with appropriate software and calibration data for the product "yoghurt". Whey total protein was tested in supernatant of the fermented milk after centrifugation at $3000 \mathrm{~g} 15 \mathrm{~min}$. To measure the acidification rate, a $2 \% \mathrm{w} / \mathrm{v}$ dispersion of the fermented milk was shaken in pure water for $5 \mathrm{~min}$ and the $\mathrm{pH}$ was determined. TTA was measured as described above by titration with $\mathrm{NaOH}$ in presence of phenolphthalein.

To determine the water holding capacity, $20 \mathrm{~g}$ of fermented milk (Y) after cooling to $+4{ }^{\circ} \mathrm{C}$ for $24 \mathrm{~h}$ was centrifuged for $10 \mathrm{~min}$ at $3000 \mathrm{rpm}$, the released whey (W) was removed and weighed. The Water-holding capacity (WHC) of fermented milk was calculated as $\mathrm{WHC}=(\mathrm{Y}-$ $\mathrm{W}) / \mathrm{Y} \times 100 \%$. To measure the syneresis centrifugation has been performed at $500 \mathrm{rpm}$ for $5 \mathrm{~min}$. The syneresis 
was expressed in grams of supernatant per $100 \mathrm{~g}$ of the product.

\section{Statistical analysis}

All experiments were performed in biological triplicates with three repeats in each run. The data were analyzed and graphically visualized using GraphPad Prism version 6.00 for Windows (GraphPad Software, USA, www. graphpad.com). In each experiment, comparison against the reference strain has been performed using the nonparametric Kruskal-Wallis one-way analysis of variance test. For the drop-plate assays results assessed from 10fold dilutions, where typically only in the two latter dilutions the number of colonies was countable, to assess the statistical significance, we compared $10 \log _{10}(c)$, where $c$ is the obtained cell number, using the Pearson's chi-squared homogeneity test. For both tests significant differences were reported at $p<0.05$.

\section{Supplementary information}

Supplementary information accompanies this paper at https://doi.org/10. 1186/s12866-019-1618-0.

Additional file 1: Figure S1. Viability of $L A B$ strains when growing for $24 \mathrm{~h}$ in presence of 48 -h old biofilms of pathogenic bacteria. After $24 \mathrm{~h}$ CFUs of bacteria were calculated by seeding on MRS. Asterisks denote statistically significant difference with monocultures of corresponding $\mathrm{LAB}(p<0.05)$. Figure $\mathbf{S 2}$. Viability of $L A B$ strains during co-cultivation with pathogenic bacteria. After $48 \mathrm{~h}$ CFUs of bacteria were calculated by seeding on MRS. Asterisks denote statistically significant difference with monocultures of corresponding LAB $(p<0.05)$. Figure S3. Viability of $L A B$ strains when growing in MRS with 10 -fold reduced glucose content $(0.2 \%)$ for $24 \mathrm{~h}$ in presence of 48 -h old biofilms of pathogenic bacteria. After $24 \mathrm{~h}$ CFUs of bacteria were calculated by seeding on MRS. Asterisks denote statistically significant difference with monocultures of corresponding $L A B(p<0.05)$. Figure S4. Viability of $L A B$ strains during $C^{-}$ cultivation with pathogenic bacteria in MRS with 10-fold reduced glucose content (0.2\%). After $48 \mathrm{~h}$ CFUs of bacteria were calculated by seeding on MRS. Asterisks denote statistically significant difference with monocultures of corresponding LAB $(p<0.05)$.

\section{Acknowledgements}

Not applicable.

\section{Authors' contributions}

Conceptualization, AK, DY and EN; Methodology, AK, DY; Investigation, EA, EG, AG, AV; Data Curation, MB.; Writing-Original Draft Preparation, AK, DY, EN, MB; Writing-Review \& Editing, AK, DY, EN, MB; Visualization, EG, EA; Supervision, AK; Project Administration, AK, DY.; Funding Acquisition, AK. All the authors have read and approved the manuscript.

\section{Funding}

This research was funded by the Russian Foundation for Basic Research grant number 17-00-00456 and by the Ministry of Education and Science of the Russian Federation assignment number 2.5475.2017/6.7.

\section{Availability of data and materials}

The datasets used and/or analyzed during the current study are available from the corresponding author on reasonable request.

Ethics approval and consent to participate Not applicable.
Consent for publication

Not applicable.

\section{Competing interests}

The authors declare that they have no competing interests.

\section{Author details}

${ }^{1}$ Kazan Federal University, 18 Kremlevskaya Str, 420008 Kazan, Russia. ${ }^{2}$ Kazan National Research Technological University, 68 Karl Marx Str, 420015 Kazan, Russia. ${ }^{3}$ Saint-Petersburg Electrotechnical University, 5 Professor Popov str, 197376 St. Petersburg, Russia.

Received: 19 August 2018 Accepted: 22 October 2019

Published online: 08 November 2019

\section{References}

1. Steinkraus KH. Fermented foods, feeds, and beverages. Biotechnol Adv. 1986;4(2):219-43.

2. Özogul F, Hamed I. The importance of lactic acid bacteria for the prevention of bacterial growth and their biogenic amines formation: a review. Crit Rev Food Sci Nutr. 2018;58(10):1660-70.

3. Ayala DI, Cook PW, Franco JG, Bugarel M, Kottapalli KR, Loneragan GH, et al A systematic approach to identify and characterize the effectiveness and safety of novel probiotic strains to control foodborne pathogens. Front Microbiol. 2019;10:1108.

4. Son $\mathrm{SH}$, Jeon $\mathrm{HL}$, Yang SJ, Lee NK, Paik HD. In vitro characterization of lactobacillus brevis KU15006, an isolate from kimchi, reveals anti-adhesion activity against foodborne pathogens and antidiabetic properties. Microb Pathog. 2017;112:135-41

5. Gao Z, Daliri EB, Wang J, Liu D, Chen S, Ye X, et al. Inhibitory effect of lactic acid bacteria on foodborne pathogens: a review. J Food Prot. 2019;82(3):441-53.

6. Lejeune JT, Rajala-Schultz PJ. Food safety: unpasteurized milk: a continued public health threat. Clin Infect Dis. 2009;48(1):93-100.

7. De Buyser ML, Dufour B, Maire M, Lafarge V. Implication of milk and milk products in food-borne diseases in France and in different industrialised countries. Int J Food Microbiol. 2001;67(1-2):1-17.

8. Coda R, Nionelli L, Rizzello CG, De Angelis M, Tossut P, Gobbetti M. Spelt and emmer flours: characterization of the lactic acid bacteria microbiota and selection of mixed starters for bread making. J Appl Microbiol. 2010;108(3):925-35.

9. Messens W, De VL. Inhibitory substances produced by lactobacilli isolated from sourdoughs--a review. Int J Food Microbiol. 2002;72(1-2):31-43.

10. Messens W, Neysens P, Vansieleghem W, Vanderhoeven J, De Vuyst L. Modeling growth and bacteriocin production by lactobacillus amylovorus DCE 471 in response to temperature and $\mathrm{pH}$ values used for sourdough fermentations. Appl Environ Microbiol. 2002;68(3):1431-5.

11. Bridier A, Sanchez-Vizuete P, Guilbaud M, Piard JC, Naïtali M, Briandet R. Biofilm-associated persistence of food-borne pathogens. Food Microbiol. 2015:45(Pt B):167-78.

12. Pérez-lbarreche M, Castellano P, Leclercq A, Vignolo G. Control of Listeria monocytogenes biofilms on industrial surfaces by the bacteriocin-producing lactobacillus sakei CRL1862. FEMS Microbiol Lett. 2016;363(12):fnw118.

13. Giaouris E, Heir E, Hébraud M, Chorianopoulos N, Langsrud S, Møretrø T, et al. Attachment and biofilm formation by foodborne bacteria in meat processing environments: causes, implications, role of bacterial interactions and control by alternative novel methods. Meat Sci. 2014;97(3):298-309.

14. Giaouris E, Heir E, Desvaux M, Hebraud M, Moretro T, Langsrud S, et al. Infraand inter-species interactions within biofilms of important foodborne bacterial pathogens. Front Microbiol. 2015;6:841.

15. Lewis K. Riddle of biofilm resistance. Antimicrob Agents Chemother. 2001; 45(4):999-1007.

16. Fagerlund A, Langsrud S, Heir E, Mikkelsen MI, Moretro T. Biofilm matrix composition affects the susceptibility of food associated staphylococci to cleaning and disinfection agents. Front Microbiol. 2016;7:856.

17. Atshan SS, Shamsudin MN, Sekawi Z, Lung LTT, Barantalab F, Liew YK, et al. Comparative proteomic analysis of extracellular proteins expressed by various clonal types of Staphylococcus aureus and during planktonic growth and biofilm development. Front Microbiol. 2015;6:524.

18. Donlan RM. Biofilms: microbial life on surfaces. Emerg Infect Dis. 2002;8(9):881-90. 
19. Cosgrove SE, Kaye KS, Eliopoulous GM, Carmeli Y. Health and economic outcomes of the emergence of third-generation cephalosporin resistance in Enterobacter species. Arch Intern Med. 2002;162(2):185-90.

20. Sanchez-Vizuete P, Orgaz B, Aymerich S, Le Coq D, Briandet R. Pathogens protection against the action of disinfectants in multispecies biofilms. Front Microbiol. 2015;6:705.

21. Kayumov AR, Nureeva AA, Trizna EY, Gazizova GR, Bogachev MI, Shtyrlin NV, et al. New derivatives of pyridoxine exhibit high antibacterial activity against biofilm-embedded staphylococcus cells. Biomed Res Int. 2015;10:890968.

22. Shtyrlin NV, Sapozhnikov SV, Koshkin SA, Iksanova AG, Sabirov AH, Kayumov $A R$, et al. Synthesis and antibacterial activity of novel quaternary ammonium pyridoxine derivatives. Med Chem. 2015;11(7):656-65.

23. Kang MS, Lim HS, Oh JS, Lim YJ, Wuertz-Kozak K, Harro JM, et al. Antimicrobial activity of lactobacillus salivarius and Lactobacillus fermentum against Staphylococcus aureus. Pathog Dis. 2017;75(2):ftx009.

24. Melo TA, Dos Santos TF, de Almeida ME, Junior LA, Andrade EF, Rezende RP, et al. Inhibition of Staphylococcus aureus biofilm by lactobacillus isolated from fine cocoa. BMC Microbiol. 2016;16(1):250.

25. Rybalchenko OV, Bondarenko VM, Orlova OG, Markov AG, Amasheh S. Inhibitory effects of lactobacillus fermentum on microbial growth and biofilm formation. Arch Microbiol. 2015;197(8):1027-32.

26. Shokri D, Khorasgani MR, Mohkam M, Fatemi SM, Ghasemi Y, Taheri-Kafrani A The inhibition effect of lactobacilli against growth and biofilm formation of Pseudomonas aeruginosa. Probiotics Antimicrob Proteins. 2018;10(1):34-42.

27. Berríos P, Fuentes JA, Salas D, Carreño A, Aldea P, Fernández F, et al. Inhibitory effect of biofilm-forming lactobacillus kunkeei strains against virulent Pseudomonas aeruginosa in vitro and in honeycomb moth (galleria mellonella) infection model. Benef Microbes. 2018;9(2):257-68.

28. Petrova MI, Imholz NC, Verhoeven TL, Balzarini J, Van Damme EJ, Schols D, et al. Lectin-like molecules of lactobacillus rhamnosus GG inhibit pathogenic Escherichia coli and salmonella biofilm formation. PLoS One. 2016;11(8):e0161337.

29. Gómez NC, Ramiro JM, Quecan BX, de Melo Franco BD. Use of potential probiotic lactic acid bacteria (LAB) biofilms for the control of listeria monocytogenes, salmonella typhimurium, and Escherichia coli 0157:H7 biofilms formation. Front Microbiol. 2016;7:863.

30. Carnevali P, Ciati R, Leporati A, Paese M. Liquid sourdough fermentation: industrial application perspectives. Food Microbiol. 2007;24(2):150-4

31. Stefanovic E, Kilcawley KN, Rea MC, Fitzgerald GF, McAuliffe O. Genetic, enzymatic and metabolite profiling of the lactobacillus casei group reveals strain biodiversity and potential applications for flavour diversification. J Appl Microbiol. 2017;122(5):1245-61.

32. Stefanovic E, Fitzgerald G, McAuliffe O. Advances in the genomics and metabolomics of dairy lactobacilli: a review. Food Microbiol. 2017;61:33-49.

33. Bosma EF, Forster J, Nielsen AT. Lactobacilli and pediococci as versatile cell factories - evaluation of strain properties and genetic tools. Biotechnol Adv. 2017:35(4):419-42.

34. Rhee $\mathrm{SJ}$, Lee JE, Lee $\mathrm{CH}$. Importance of lactic acid bacteria in Asian fermented foods. Microb Cell Factories. 2011:10 Suppl 1:S5.

35. Wang D, Liu W, Ren Y, De L, Zhang D, Yang Y, et al. Isolation and identification of lactic acid bacteria from traditional dairy products in Baotou and Bayannur of Midwestern Inner Mongolia and q-PCR analysis of predominant species. Korean J Food Sci Anim Resour. 2016;36(4):499-507.

36. Franciosi E, Carafa I, Nardin T, Schiavon S, Poznanski E, Cavazza A, et al. Biodiversity and $\gamma$-aminobutyric acid production by lactic acid bacteria isolated from traditional alpine raw cow's milk cheeses. Biomed Res Int. 2015;2015:625740

37. Foligné B, Daniel C, Pot B. Probiotics from research to market: the possibilities, risks and challenges. Curr Opin Microbiol. 2013;16(3):284-92.

38. Solieri L, Bianchi A, Mottolese G, Lemmetti F, Giudici P. Tailoring the probiotic potential of non-starter lactobacillus strains from ripened Parmigiano Reggiano cheese by in vitro screening and principal component analysis. Food Microbiol. 2014;38:240-9.

39. Sornplang P, Piyadeatsoontorn S. Probiotic isolates from unconventional sources: a review. J Anim Sci Technol. 2016;58:26.

40. Ennahar S, Cai Y, Fujita Y. Phylogenetic diversity of lactic acid bacteria associated with paddy rice silage as determined by $16 \mathrm{~S}$ ribosomal DNA analysis. Appl Environ Microbiol. 2003;69(1):444-51.

41. Doi K, Nishizaki Y, Kimura H, Kitahara M, Fujino Y, Ohmomo S, et al. Identification of thermo tolerant lactic acid bacteria isolated from silage prepared in the hot and humid climate of southwestern Japan. Springerplus. 2013;2:485.
42. Tanizawa Y, Tohno M, Kaminuma E, Nakamura Y, Arita M. Complete genome sequence and analysis of lactobacillus hokkaidonensis LOOC260(T), a psychrotrophic lactic acid bacterium isolated from silage. BMC Genomics. 2015;16:240.

43. Hotterbeekx A, Xavier BB, Bielen K, Lammens C, Moons P, Schepens T, et al. The endotracheal tube microbiome associated with Pseudomonas aeruginosa or Staphylococcus epidermidis. Sci Rep. 2016;6:36507.

44. Ahumada MC, Colloca M, López M, de Ruiz Holgado AP, Nader-Macias M. Characterization of lactobacilli isolated from the tongue and gum. Anaerobe. 1999;3(5):129-35.

45. Melo TA, Dos Santos TF, Pereira LR, Passos HM, Rezende RP, Romano CC. Functional profile evaluation of Lactobacillus fermentum TCUESC01: a new potential probiotic strain isolated during cocoa fermentation. Biomed Res Int. 2017;2017:5165916.

46. Sharafutdinov IS, Pavlova AS, Khabibrakhmanova AM, Faizova RG, Kurbangalieva AR, Tanaka K, et al. Targeting Bacillus cereus cells: increasing efficiency of antimicrobials by the bornylpossessing 2(5H)-furanone derivative. New Microbiol. 2019;42(1):29-36.

47. Botes $M$, Loos B, van Reenen CA, Dicks LM. Adhesion of the probiotic strains enterococcus mundtii ST4SA and lactobacillus plantarum 423 to Caco-2 cells under conditions simulating the intestinal tract, and in the presence of antibiotics and anti-inflammatory medicaments. Arch Microbiol. 2008;190(5):573-84.

48. Duary RK, Rajput YS, Batish VK, Grover S. Assessing the adhesion of putative indigenous probiotic lactobacilli to human colonic epithelial cells. Indian J Med Res. 2011;134(5):664-71.

49. Tsapieva A, Duplik N, Suvorov A. Structure of plantaricin locus of lactobacillus plantarum 8P-A3. Benef Microbes. 2011;2(4):255-61.

50. Schillinger $U$, Lücke FK. Antibacterial activity of lactobacillus sake isolated from meat. Appl Environ Microbiol. 1989;55(8):1901-6.

51. Kayumov AR, Khakimullina EN, Sharafutdinov IS, Trizna EY, Latypova LZ, Lien $H T$, et al. Inhibition of biofilm formation in Bacillus subtilis by new halogenated furanones. J Antibiot. 2015;68(5):297-301.

52. Trizna EY, Khakimullina EN, Latypova LZ, Kurbangalieva AR, Sharafutdinov IS, Evtyugin VG, et al. Thio derivatives of $2(5 \mathrm{H})$-Furanone as inhibitors against Bacillus subtilis biofilms. Acta Nat. 2015;7(2):102-7.

53. Baidamshina DR, Trizna EY, Holyavka MG, Bogachev MI, Artyukhov VG, Akhatova FS, et al. Targeting microbial biofilms using Ficin, a nonspecific plant protease. Sci Rep. 2017;7:46068.

54. Herigstad B, Hamilton $M$, Heersink J. How to optimize the drop plate method for enumerating bacteria. J Microbiol Methods. 2001;44(2):121-9.

55. Sharafutdinov IS, Trizna EY, Baidamshina DR, Ryzhikova MN, Sibgatullina RR, Khabibrakhmanova AM, et al. Antimicrobial effects of sulfonyl derivative of 2(5H)-Furanone against planktonic and biofilm associated methicillinresistant and -susceptible Staphylococcus aureus. Front Microbiol. 2017;8: 2246.

56. Beumer RR, de Vries J, Rombouts FM. Campylobacter jejuni non-culturable coccoid cells. Int J Food Microbiol. 1992;15(1-2):153-63.

57. Rosenberg M. Microbial adhesion to hydrocarbons: twenty-five years of doing MATH. FEMS Microbiol Lett. 2006;262(2):129-34.

58. Kos B, Suskovic J, Vukovic S, Simpraga M, Frece J, Matosic S. Adhesion and aggregation ability of probiotic strain lactobacillus acidophilus M92. J Appl Microbiol. 2003;94(6):981-7.

59. Bruslik NL, Akhatova DR, Toimentseva AA, Abdulkhakov SR, Ilyinskaya ON, Yarullina DR. Estimation of probiotic lactobacilli drug resistance. Antibiot Khimioter. 2015;60(3-4):6-13.

60. Locher HH, Ritz D, Pfaff P, Gaertner M, Knezevic A, Sabato D, et al. Dimers of Nostocarboline with potent antibacterial activity. Chemotherapy. 2010;56(4):318-24.

61. Yoon J-H, Lee ST, Park Y-H. Inter-and intraspecific phylogenetic analysis of the genus Nocardioides and related taxa based on $16 \mathrm{~S}$ rDNA sequences. Int J Syst Evol Microbiol. 1998;48(1):187-94.

62. McGarvey JA, Franco RB, Palumbo JD, Hnasko R, Stanker L, Mitloehner FM. Bacterial population dynamics during the ensiling of Medicago sativa (alfalfa) and subsequent exposure to air. J Appl Microbiol. 2013;114(6):1661-70.

63. Anisimova E, Yarullina D. Characterization of erythromycin and tetracycline resistance in lactobacillus fermentum strains. Int J Microbiol. 2018;2018: 3912326.

\section{Publisher's Note}

Springer Nature remains neutral with regard to jurisdictional claims in published maps and institutional affiliations. 